History of Biology", Junge "had a real insight for classification, grouping plants according to the formation of their flowers, and naming the groups Compositae, Labiatae and Leguminosae", names which still remain. The paper which follows, on "Experiment in the Medicine of the Seventeenth Century", gives an interesting account of this important epoch in medical history, and is contributed by Prof. J. Steudel, of Bonn. It is illustrated by eleven figures, showing some experiments of Harvey, de Graaf, Boyle, Mayow and others. Prof. W. Flitner, of Hamburg, describes the logic and philosophy of the period, and his colleague, Prof. D. K. Deitrich Schmidt, discusses the changing outlook of theology in the days of Junge.

The scope of this excellent collection of monographs is extended even more widely by a thoughtful and suggestive study by Prof. Karl Bauch, Freiburg, of the new approach to art, adopted by Raphacl, Rubens and other artists in the opening years of the century under review. Twelve illustrations in this paper are of much interest. Finally, an appropriate background to the whole scone is provided by Prof. Otto Brunner in an essay on "Hamburg's Historical Position during the Lifetime of Joachim Jungius". 'This article, also appropriately illustrated, should prove valuable as a reference to the contemporary topography of the city. Too often, in writing of the history of science, this essential basis of social history is omitted. The Joachim Jungius Socioty is to be warmly congratulated on the publication of this timely and attractive little volume, which not only pays a fitting tribute to the work of a forgotten genius but also builds upon that work an edifice well worthy of so sound a foundation.
Douglas Guthrie:

\title{
EDUCATION IN THE AGE OF SCIENCE
}

$I^{\mathrm{N}}$ a recent issue of Daedalus (88, No. $1 ; 1959)$, ten distinguished American correspondents examino different aspects of American education and their place in a rapidly evolving scientific and technological age. The articles are grouped in five pairs, each pair representing two different points of view regarding the same aspect of education. The problem of Prof. Sidney Hook and George N. Shuster is that of the general nature and ends of education. Prof. Hook holds that the ends are threefold: to produce skills, knowledge and loyalties. On all three aspects there is a difference of opinion. If 'skills' mean the ability to think, speak and write effectively, education must clearly aim at such skills; but do they include skills of everyday living ? Here there are rigorists and latitudinarians. Regarding know. ledge and loyalties, the differences go deeper. Prof. Hook is a secularist who believes that the only knowledge worthy of the name is that which is accredited by scientific method, and that even moral judgments are subject to empirical tests. Shuster believes that theology is the queen of the sciences, and that the most sure and important knowledge has another kind of certification altogether.

In the papers of the socond group, Prof. Douglas Bush states the case for the humanities in education, and Prof. Ernest Nagel the case for the sciences. Both advocates recognize that both disciplines are essential but they differ about two points. Prof. Bush, eoncerned about the 'sophisticated vulgarity' of newspapers, best-sellers, radio, advertising and music, thinks that much of this is a by-product of science, partly through its technical applications, partly through the exaltation of science in the popular mind. Science has made 'mass eivilization' possible, and 'the religion of commonness' that has resulted has been creeping out from news-stands and films into the schools and universities. Science provides the means by which a commercial civilization may exploit the mind more expertly, but no corresponding resistances against the shoddiness of mass values; nor does it do anything to prevent the 'spiritual impoverishment of the expert' himself.

Prof. Nagel, admitting the part of science in helping to produce mass culture, replies that it is unjust to make science responsible for men's misuses of it, and argues that our mass culture, for all its defects, represents a high-water mark in democratic education. He then makes a claim for science that provides a second bone of contention, believing that scientifie method, taken broadly as the method by which propositions are validated, is the sole and sufficient means of establishing any kind of knowledge. The judgments of value passed by a humanist upon poetry or music may be merely expressions of his feeling; but if they say more than that, if they offer themselves as true, there is only one way of establishing them, and that is the approved way of science. Bush, Shuster and others do not agree. They hold that the poet, the religious man, and the critic have insights that such a method is inadequate to appraise. Here, as elsewhere, it becomes clear how difficult it is to talk about education without entering into philosophy.

The chief issue of the third group is raised by Prof. Arthur Bestor's contention that American schools are trying to do too much. If all three ends -skills, loyalties and intellectual discipline--are important, can a school sensibly try to achieve all of them? Perhaps a residential school can, since it has full control of the pupil's time. A day school cannot; if, with a few hours a day at its disposal, it tries to take over the functions once performed by home, church and work, as well as to discipline the young mind, it will do all of them badly. Prof. Bestor's proposal for American schools is clear-cut: let them realize that they are over-extending themsolves and close their ranks, so that they can perform their own function well-that function being distinctively intelleetual. To maintain their standards in the face of local pressures, they should set up State-wide systems of examination, which would free the able students from the educational 'lock step' and would test actual achievement rather than accumulations of credits and hours.

Prof. Bestor's views aro challenged at several points by Prof. John L. Childs, who argues that the sensitivity of American schools to the social needs of their pupils is an advantage, not a weakness, and that the schools are not to be improved by a return to the narrow intellectualism of the French and other systems.

The issue raised by the two papers in the fourih group is: What can the schools do to prepare their 
students for the sort of citizenship demanded by the United States' new place in the world ? Dr. Reinhold Niebuhr tries to make this new place clear. It is one in which three new conditions prevail : America has become the acknowledged leader of the free world; is faced with a powerful and resolute rival ; and must apparently live with a 'nuclear stalemate'. In this precarious position, technology is no doubt important ; but Dr. Niebuhr thinks that an understanding of Russian imperialism and the curious American 'antiimperialist imperialism' is equally so. It is necessary to have representatives abroad who speak the languages and understand the cultures of those among whom they are living; and though there is no study that will enable one to forecast the future, the study that does most to equip one for understanding the larger problems of the day is history.

Hans Morgenthau puts his emphasis in a different place. Agreeing that history is important, he thinks it could best be taught and understood not as a string of events but as the exemplification of principle, and above all, the principle that nations seek power. A thorough grasp of this principle, as exemplified historically, would throw more light on the present scene than any study of the events or personalities of the day.

The fifth group of articles examines the social matrix within which education in the United States operates. Prof. Margaret Mead looks into the reasons for the separation between the world of the scientist and that of his intended audience, the general population. In this way she points to the mechanism that may be responsible for the widening of the gap between the intellectual and society at large. Prof. David Riesman directs attention to the medium in which the academic himself grows and moves-lest educators seek the sources of their difficulties only outside the sphere of their own organizational setting.

Most of the papers have been edited by Prof. Brand Blanshard, who has also contributed an introduetion to them. For background, this special issue of Daedalus also contains a reprint of A. N. Whitehead's famous essay on "The Aims of Education", which was first written some forty years ago. For those concerned with education, this essay may serve the purpose of periodic re-dedication as well as any other source.

\section{PUBLIC LIBRARIES IN ENGLAND AND WALES}

$\mathrm{T}$ HE report of the Committee appointed by the Minister of Education in September 1957 to consider the structure of the public library service in England and Wales* reviews briefly the development of the public library service and the changing views of its functions, particularly the changes in formal structure since the Kenyon Committee reported in 1927. Turning then to the public library service to-day, it suggests that three main questions arise : how a really adequate service throughout the country can best be provided; the standards for judging the efficiency of a library service; and the requisite conditions which will enable a local authority to provide an efficient service. Chapters on the future structure of public library administration, library co-operation, staff and premises, the position in Wales, library charges and library legislation follow. The principal recommendations are that the Minister of Education, assisted by two advisory bodies for England and Wales, respectively, should exercise a general responsibility for the public library service, with powers to enforce the discharge of its statutory duty by any library authority he considers to be in default. Every public library authority should have a statutory duty to provide an efficient library service, and the minimum annual expenditure on the purchase of books expected from a non-county borough or urban district council as an independent library authority should be $£ 5,000$ or $2 s$. per head of the population. All library authorities should be given powers to appoint library committees diroctly responsible to the councils.

The existing regional committees should be given statutory recognition and required, under schemes approved by the Minister, to provide a satisfactory system of library co-operation within their regions and to work in conjunction with the National Central

* Ministry of Education. The structure of the Public Library Service in England and Wales: Report of the Committee appointed by the Ministry of Education in September 1957. Pp. iv +57 . (Cmnd 660.) (London : H.M. Stationery Office, 1959.) 3s. 6d. net.
Library. The local authorities should contribute substantially to the cost of the National Central Library, with greater representation on its governing body and in its administration. An adequate series of regional catalogues and the catalogue at the National Central Library should be completed as a rnatter of urgency and with a non-recurrent Treasury grant. Extra-distriet charges should be abolished for readers using libraries outside their own areas. Salary scales for the staff of public libraries should be commensurate with their qualifications and responsibilities and so applied as to make career prospects attractive. To meet the need for considerable improvement in public library premises and for many new library buildings a higher priority should be given to capital expenditure for this purpose. No charge should be made to borrowers of books or other material except for notification that the book or material is available or for retention beyond a prescribed period, and legislative provision should be made authorizing the levying of these charges by library authorities.

A new Public Libraries Act should be passed to give effect, so far as is necessary, to these recommendations and giving all library authorities specific powers to combine or co-operate with each other, and with education and other authorities, to provide lectures and cultural activities, to provide and lend such material as gramophone records and films and to acquire land compulsorily for library purposes under the Act. It is also recommended that the position of local authorities responsible for museum and art galleries should be considered, since it may be necessary to legislate separately for librarios, museums and art galleries in future. A minority report by $\mathrm{Mr}$. J. Bulman and $\mathrm{Mr}$. S. J. Skillen enters reservations as to the type of local authority which should become or remain library authorities and dissents from the suggestion as to a minimum expenditure on books. 